\title{
Analysis on Muslim Consumer Behavior toward the Halal Certification of Bakery Products
}

\author{
Mustika Rimadhani ${ }^{1}$, Lukman M Baga $^{2}$, Sahara $^{3}$ \\ ${ }^{1}$ School of Business, Bogor Agricultural University (IPB), Jl. Raya Padjajaran Bogor Indonesia 16151, Indonesia \\ ${ }^{2}$ Department of Agribusiness, Faculty of Economics and Management, Bogor Agricultural University (IPB), Jl. Agatis Kampus IPB \\ Dramaga, Indonesia \\ ${ }^{3}$ Department of Economics, Faculty of Economics and Management, Bogor Agricultural University (IPB), J1. Kamper Kampus IPB \\ Dramaga, Indonesia
}

\begin{abstract}
Indonesia is the fourth largest country with a population of 237,641,326 people in 2010, with the Muslim population reaching $87.18 \%$ of the total Indonesian citizens (BPS, 2010). One city that has the largest population of Muslim communities in Indonesia is the city of Bogor. In 2010, the number of Muslims in the city of Bogor was 4,613,204 people or about 96.67\% of the total population. The high population of Muslims in Indonesia has encouraged increased demand for goods and services in accordance with Islamic laws, one of which is the need for food. The growing industry of bakery in Indonesia food security becomes one of the issues of concern. Food products that have undergone processing such as bakery already added with additional ingredients are very difficult to decide whether the product is kosher or not. The main objective in this study is to analyze the factors that influence the Muslim consumers' intention to continue to buy bakery products that do not have halal label, especially in the city of Bogor. The analysis model developed was based on the Theory of Planned Behavior Model approach while the method of analysis used was Structural Equation Modeling (SEM) which is one multivariate analysis techniques that can analyze relationships among variables in a more complex way. The results showed that the level of beliefs influences significantly the intention to buy bakery products that do not have halal label while subjective norms and behavioral controls have no significant effects on the intention of buying bakery products that have not been labeled halal.
\end{abstract}

Keywords: Halal Certification, Theory of Planned Behaviour Model (TPB), Structural Equation Modelling (SEM)

\section{Introduction}

Indonesia is the fourth largest country with a population of 237,641,326 people in 2010, with the Muslim population reaching $87.18 \%$ of the total Indonesian citizens (BPS, 2010). One city that has the largest population of Muslim communities in Indonesia is the city of Bogor. In 2010, the number of Muslims in this city was as many as 4,613,204 people or about $96.67 \%$ of the total population. High population of Muslims in Indonesia has encouraged increased demand for goods and services in accordance with Islamic laws, one of which is the need for food.

For producers, this condition is an opportunity to channel or create halal products, especially food products whose demands continue to increase. As one example, in 2006 McDonald in Singapore experienced an increase in the number of visits by 8 million visitors after it obtained the halal certification while KFC, Burger King and Taco Bell also increased their sales by $20 \%$ after they obtained the halal certification (Lada, Tanakinjal and Amin, 2009).

In its development, the bakery industry in Indonesia continues to experience significant growth. The development of the era of globalization and income increase in the communities followed by changes in their increasingly dynamic and practical lifestyles have become the driving factor of the growth of bakery industry in Indonesia. Bakery is part of patisseries consisting of bread, cakes, pastries, and cookies. Currently, bread is not only a side dish but it has also become staple food for a large number of people in
Indonesia especially those living in urban areas.

Table 1: Development of Bakery Industry in Indonesia

\begin{tabular}{|c|c|}
\hline Year & Values of Bakery Industry (in Rupiahs) \\
\hline 2010 & $9,260,086,889$ \\
\hline 2011 & $9,481,778,838$ \\
\hline 2012 & $12,490,778,426$ \\
\hline 2013 & $18,187,845,797$ \\
\hline
\end{tabular}

Source: Indonesia Statistics (2014)

Due to the growth of bakery industry in Indonesia, food safety has become one of the issues of concern. This is because Indonesia has experienced several events related to food safety issues that make the people restless in which they found that some food and beverage products contained some pork material, especially imported products from countries where the majority of their citizens are not Muslim. Marzuki et al (2012) stated that halal food is not limited to slaughtering process or halal meat only, but food is halal if the process starting from the production, handling, distribution, storage, display, packaging, labeling, preparation and service is conducted in accordance with the Islamic laws.

Food products that have undergone processing such as bakery which has already been added with additional ingredients will make it difficult for Muslim consumers to determine whether the products are halal or not. Based on the data from LPPOM-MUI, the number of halal certified products in Indonesia is still relatively small. In 2010-2015, there were 276,573 products, and only about 12.47 percent or 34,502 products that had halal certification, and the

Volume 6 Issue 7, July 2017 www.ijsr.net 


\section{International Journal of Science and Research (IJSR) \\ ISSN (Online): 2319-7064}

Index Copernicus Value (2015): 78.96 Impact Factor (2015): 6.391

remaining 87.53 percent or 242,071 products had no halal certification.

Table 2: Statistics of Halal Certification in Indonesia

\begin{tabular}{|c|c|c|c|}
\hline Year & $\begin{array}{c}\text { Number of Halal } \\
\text { Certification }\end{array}$ & $\begin{array}{c}\text { Number of } \\
\text { Products }\end{array}$ & $\begin{array}{c}\text { Number of } \\
\text { Companies }\end{array}$ \\
\hline 2010 & 750 & 27.121 & 692 \\
\hline 2011 & 4.869 & 39.002 & 4.325 \\
\hline 2012 & 6.157 & 32.890 & 5.829 \\
\hline 2013 & 7.014 & 64.121 & 6.666 \\
\hline 2014 & 10.322 & 68.576 & 10.180 \\
\hline Jan-July 2015 & 5.390 & 44.863 & 4.984 \\
\hline Total & 34.502 & 276.573 & 32.676 \\
\hline
\end{tabular}

Source: LPPOM-MUI, 2015

The behavior of Muslim consumers in consuming halal products is highly dependent on the knowledge and understanding on the concept of halal. The behavior in consuming halal products can be examined from the frequency of their halal-labeled product consumption, frequency of consuming products which are not guaranteed halal, their frequency of being driven to invite others to consume halal products and prevent others from consuming non-halal products.

In accordance with the research conducted by Ambali and Bakar (2013) on "Halal Food and Products in Malaysia: People's Awareness and Policy Implications", this study aims to analyze the determinants of Muslim consumer awareness towards halal products or foods in Shah Alam City, Selangor, Malaysia. The method used in the research was Partial Least Square-SEM. The results show that most respondents in Shah Alam are aware of consuming halal products or foods which reflect their adherence to Muslim way of life. The study also highlights that four constructs in the models of halal exposure, religious beliefs, health reasons, and role of halal certification (halal logo or label) are the original indicators of Muslim awareness towards food and halal products. This shows that there is a positive relationship between all the identified determinants and level of awareness towards halal products and food among Muslims in Shah Alam.

In the research conducted by Natural and Nazura (2011) on "Applying the Theory of Planned Behavior (TPB) in Halal Food Purchasing", this study also aims to explore how TPB is capable of facilitating the attempt to predict the desire to purchase halal food products in Malaysia. The results showed that there is a significant and positive relationship between the attitudes and desire to purchase halal food products, and there was a significant and positive relationship between the perceived behavior control and halal food product consumption. Moreover, there was a significant and positive relationship between the perceived behavior controls and halal food product consumption. The TPB model seemed to effectively predict the consumers' intention in consuming halal food in Malaysia.

\section{Theory of Planned Behavior}

Theory of Planned Behavior Model (TPB) is an attitude model developed from the Theory of Reasoned Action (TRA) attitude model. This model was also developed from
Fishbein's multi-attribute model. This Theory of Planned Behavior Model (TPB) is an attitude model that estimates the interest or intention of consumers to perform a behavior or action. It also explains that the main factor affecting a person's behavior is the intention or tendency to perform such action (Sumarwan, 2011).

The fundamental concept of Theory of Planned Behavior Model (TPB), according to Ajzen (1991), is that human behavior is firstly influenced by interest (behavior intentions). The interest will be influenced by the three following main factors.

1. Attitudes toward behavior

Attitude reflects the overall evaluation of the behavior practice. One's attitude toward a particular behavior is resulted from two factors: one's belief in the outcome of a behavior and an outcome evaluation.

2. Subjective norms

Subjective norms, as social elements, are one's belief in what other people think about what they should do and one's motivation to follow their assumptions (normative beliefs and the motivation to comply them). Subjective Norms reflect a person's perception on what others want them to do.

3. Perceived behavioral control (perceived behavioral control).

Perceived behavioral control refers to a person's perception on his or her ability to present certain behaviors. It is determined by beliefs in factors that may facilitate or complicate the practice of controlled behaviors (control beliefs).Behavior control also shows the extent to which a person feels that presenting or not presenting a particular behavior is under the control of the individual concerned (power of control factor).

In Theory of Planned Behavior Model (TPB), the main factor of a person's behavior is the intention to display certain behaviors (Ajzen, 1991). Intention is presumed as a motivational factor affecting behavior, and it is an indication of how much effort someone puts to perform a behavior. The harder a person's intention to engage in a behavior, the greater the tendency is to actually perform that behavior. In addition to motivational factors, how far a person presents behavior also depends on non-motivational factors; for instance, the availability of opportunities and resources (e.g. money, time, and third party's support). Simultaneously, these factors reflect actual control over behavior. If opportunities and resources are available, and there is an intention to present behavior, the chance of the behavior to show up is fairly high. In other words, a behavior will arise if there is a motivation (intention) and capability (behavior control) (Hisham, 2009). 


\section{International Journal of Science and Research (IJSR) \\ ISSN (Online): 2319-7064}

Index Copernicus Value (2015): 78.96 | Impact Factor (2015): 6.391

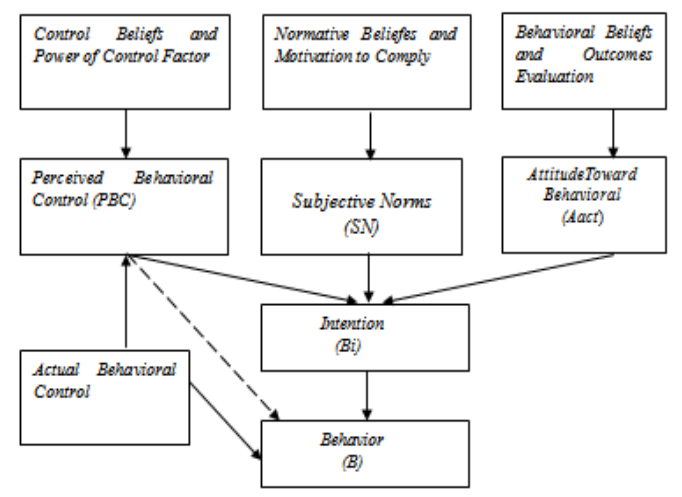

Figure 1: Theory of Planned Behavior (Source: Ajzen, 2006)

\section{Data}

The data used in this study were primary data obtained from interviews and questionnaires of bakery product consumers (Muslim consumers in Botani Square). The technique of sampling is non-probability sampling technique. Convenience sampling is also conducted in accordance with the circumstances expected by the researcher (Nazir, 1988). In addition, rule of thumb of Structural Equation Modeling (SEM) was utilized as the measurement sampling. According to Hair et al. (2006), the minimum number of observations is the number of indicator variables multiplied by five to ten. The numbers of indicator variables used in SEM analysis in this study were 32 . Based on the SEM rule of thumb, the minimum number of observations ranged from 160 to 320 observations. Thus, there were 170 samples suited with the rule of thumb of SEM.

\section{Methodology}

The Chi-Square Goodness of FIT test was utilized to determine the data distribution from samples by following a particular theoretical distribution or not, or to compare a set of observed frequencies with expected frequency groups (Suliyanto, 2014). In this study, Chi-Square test was used to examine the relationship level between Muslim consumers' understanding and intention to purchase bakery products without halal label.

To reveal the factors influencing Muslim consumer intention to keep purchasing bakery products without halal label, Theory of Planned Behavior (TPB) was used as the model approach. There are two types of model variables of consumer intention in purchasing bakery products without halal label i.e. independent variables and dependent variables. The independent variables consisted of attitude toward behavioral of purchasing bakery products without halal label, subjective norms related to behavior, and perceived behavioral control). Meanwhile, the intention to purchase bakery products without halal label (behavioral intentions) is covered in the dependent variable. Furthermore, the model was utilized in conducting an analysis of Structural Equation Modeling (SEM).

\section{Empirical Result}

\subsection{Chi-Square Test}

Based on the results of Chi-Square analysis, the examination results to observe the relationship between the level of knowledge and understanding of Muslim consumers on halal label indicates a difference between consumers who understand and do not. Chi-Square analysis results of respondents who understood obtained a p-value value of $0.000<0.05$ indicating that $\mathrm{Ho}$ was rejected (Ha was accepted). Therefore, it is statistically proven that there is a different proportion of purchasing decisions by not buying bakery products without halal label for respondents who had knowledge and understanding of halal label. When the respondents have more understanding on halal label, they increase the chance of not buying products without halal label.

For the respondents who did not understand, a p-value of 0.159> 005 was obtained, indicating that Ho was accepted. Thus, it can be concluded for respondents who do not have knowledge and understanding on halal label, there are no differences in the behavior in buying or not buying bakery products that do not have halal label.

Table 3: The Results of Chi-Square Test

\begin{tabular}{|c|c|c|c|c|c|}
\hline $\begin{array}{c}\text { Respondents' } \\
\text { Understanding }\end{array}$ & Total & $\begin{array}{c}\text { Not } \\
\text { Purchasing }\end{array}$ & Purchasing & $\begin{array}{c}\text { p- } \\
\text { value }\end{array}$ & Summary \\
\hline Understood & 109 & 76 & 33 & 0,000 & $\begin{array}{c}\text { Ho was } \\
\text { rejected }\end{array}$ \\
\hline Not Understood & 61 & 36 & 25 & 0,159 & $\begin{array}{c}\text { Ho was } \\
\text { accepted }\end{array}$ \\
\hline
\end{tabular}

Source: processed data

\subsection{Analysis on Structural Equation Modelling (SEM)}

The model used in the research had be tested first, in order to determine the shape and magnitude of the influences. Therefore, parameter estimation was conducted using Structural Equating Modeling (SEM) approach. In order to make model of the purchase decision shaped in accordance with the empirical data, the Goodness of Fit Model (Conformity Model) was conducted. From the AMOS analysis, the following results were obtained:

Table 4: SEM Model Test Result

\begin{tabular}{|c|c|c|c|}
\hline $\begin{array}{c}\text { Goodness of fit } \\
\text { index }\end{array}$ & $\begin{array}{c}\text { Criteria } \\
\text { (cut-off value) }\end{array}$ & Result & Conclusion \\
\hline $\mathrm{X}^{2}$ - Chi-square & $\begin{array}{c}\text { Expected to be } \\
\text { smaller }\end{array}$ & 1039.85 & Model does not fit \\
\hline $\begin{array}{c}\text { Significance } \\
\text { probability }\end{array}$ & $\geq 0.05$ & 0.00 & Model fits \\
\hline RMSEA & $\leq 0.10$ & 0.069 & Marginal fits \\
\hline IFI & $\geq 0.90$ & 0.815 & Model does not fit \\
\hline RFI & $\geq 0.90$ & 0.684 & Model does not fit \\
\hline TLI & $\geq 0.90$ & 0.777 & Marginal model fits \\
\hline CFI & $\geq 0.90$ & 0.811 & . \\
\hline
\end{tabular}

Source: processed data

Based on Table 4 of SEM model test, RMSEA obtained a value of $0.069 \leq 0.10$ which means that the resulted model

\section{Volume 6 Issue 7, July 2017 www.ijsr.net}




\section{International Journal of Science and Research (IJSR) \\ ISSN (Online): 2319-7064}

Index Copernicus Value (2015): 78.96 | Impact Factor (2015): 6.391

has goodness of fit. The usages of other goodness of fit criteria are IFI, RFI, TLI, and CFI. IFI and CFI obtained values of 0815 and 0.811 . Thus, it can be inferred that the model is marginal fit. RFI and TLI indicators obtained the value of 0.684 and 0.777 ; therefore, the model does not have goodness of fit.
In accordance with Nugraha's research (2016), the chi-square and probability values also show poor results as the chisquare value is highly sensitive to the number of samples and indicators. After conducting a feasibility analysis of SEM model, testing the hypothesis was conducted in the next stage. The results of hypothesis testing in this study are explained in detail in Table 5.

Table 5: The estimated results of SEM Model

\begin{tabular}{|c|l|c|c|c|c|}
\hline Hypothesis & \multicolumn{1}{|c|}{ Relationship } & Estimation & C.R. & P & Conclusion \\
\hline $\mathrm{H}_{1}$ & Behavioral Belief $\rightarrow$ Intention & 2.146 & 2.821 & 0.005 & Ho was rejected \\
\hline $\mathrm{H}_{2}$ & Subjective Norm $\rightarrow$ Intention & 0.025 & 0.365 & 0.715 & Ho was accepted \\
\hline $\mathrm{H}_{3}$ & Behavioral Control $\rightarrow$ Intention & -0.220 & -0.210 & 0.833 & Ho was accepted \\
\hline
\end{tabular}

Hypothesis 1 states that behavioral beliefs have an influence on purchase intentions. In reference to the processed results, coefficient estimation was obtained by 2.146 , indicating that increased behavior beliefs will increase the purchase intention and vice versa. These findings exemplify that behavioral beliefs have a significant effect on the intention of purchasing bakery products without halal label. This can be examined in reference to the statistical value of 2.282.1 and $\mathrm{p}$-value value of $0.005<0,05$. The absence of complaints during the consumption of bakery products without halal label, as well as hygienic production place and BPOM label from the Department of Health enables today's Muslim consumers to feel safe in purchasing bakery products without halal label. It can be observed in detail by referring to the consequent evaluation factor of the variables of Muslim consumer behavior beliefs.

Hypothesis 2 states that subjective norms affect the purchase intention. Based on the result of the data, the coefficient estimation was 0,025 indicating that an increase in subjective norms will increase the purchase intention and vice versa. It is shown on the statistical values of 0.365 and p-value of $0.715>0.05$, meaning that subjective norms do not have a significant effect on the purchase intention of bakery products without halal label. The results showed that the persuasion made by friends, family environment and media appeal do not have a significant influence in determining the Muslim consumer's intention in purchasing bakery products without halal label. In this case, principally, a Muslim is guided by the Shari'a or religious suggestion advocating the use of halal products for Muslims. Subsequently, a Muslim is motivated to obey or approve behaviors that have been advocated by Shari'a or religion reinforced by preachers or other influential people.

Hypothesis 3 identifies the perceived behavior control towards purchase intentions. Based on the results, coefficient estimation was -0.220 , indicating that increased behavior control will decrease the purchase intention and vice versa. It is evident on the acquisition of statistical value of -0.210 and the p-value of $0.833>0.05$, indicating that the behavior control does not have a significant influence on the purchase intention of bakery products without halal label. This shows that Muslim consumers still own perceived behavior control to decide the intention to purchase bakery products without halal label, in accordance with the Shari'a or religious advice.

\section{Conclusions}

In reference to the results of chi-square analysis, it shows the different decision proportion of Muslim consumers that have the knowledge and understanding to buy and not to buy bakery products without halal label. The more understood the respondents, the more increase the chance for the consumers not to buy bakery products without halal label. In addition, for the respondents who were clueless, there is no difference in their behavior in buying or not buying bakery products without halal label.

Muslim consumer behavior beliefs have a significant influence on the intention of buying bakery products without halal label, whereas subjective norms and behavior controls have no significant influences on the intention of buying bakery products without halal label.

\section{References}

[1] Ajzen I. 1991. The Theory of Planned Behavior Organizational Behavior and Human Decision Processes 50, 179-211. University of Massachusetts. Amherst.

[2] Alam SS, Sayuti NM. 2011. Applying The Theory of Planned Behavior (TPB) in Halal Food Purchase. Journal of Commerce and Management. 21 (1):8-20. Doi: 0.1108/10569211111111676.

[3] Ambali AR, Bakar AN. 2013. Halal food and products in Malaysia: People's awareness and policy implications. Intellectual Discourse. 21(1).

[4] Badan Pusat Statistik. 2014. Industry Bakery: Perkembangan Industri Bakery di Indonesia.Badan Pusat Statistik,Jakarta.

[5] Hair J, Bill B, Bary JB, Rudolph AE, Rudolph LT. 2006. Mutlivariate Data Analysis Sixth Edition. New Jersey: Pearson Prentice Hall.

[6] Hisyam AB. 2009. Faktor-faktor yang mempengaruhi intensi bershodaqoh melalui badan sosial [tesis]. Depok: Universitas Indonesia

[7] Lada S, Tanakinjal GH, Amin H. (2009) Predicting intention to choose halal products using theory of reasoned action. International Journal of Islamic and Middle Eastern Finance and Management. 2(1) pp. 6676. www.emeraldinsight.com/1753-8394.

[8] Lembaga Pengkajian Pangan Obat-Obatan dan Kosmetika Majelis Ulama Indonesia. 2015. Statistik Sertifikasi Halal Indonesia. http://www.halalmui.org 
[access on November 19, 2015].

[9] Marzuki SZS, Hall CM, Ballantine PW. 2012. Restaurant Manager and Hala Certification in Malaysia. Journal of Foodservice Business Reasearch, 15:195214, 2012. Malaysia.

[10]Nazir M. 1988. Metode Penelitian. Jakarta: Ghalia Indonesia.

[11]Nugraha MR. 2016. Pemodelan social shopping relationship management dalam pembentukan relationship quality dan e-loyalty. [tesis]. Bogor (ID): Institut Pertanian Bogor.

[12] Suliyanto. 2014. Statistika Non Parametrik-Dalam Aplikasi Penelitian. Yogyakarta: Andi Offset.

[13] Sumarwan Ujang. 2011. Perilaku Konsumen. Teori dan Penerapannya dalam Pemasaran. Bogor (ID): Ghalia Indonesia.

Volume 6 Issue 7, July 2017

www.ijsr.net 